\title{
Frank Golley's Perspectives on Environmental Ethics and Literacy: How to Avoid Irreversible Impacts of Hydro-Power and Inter-Oceanic Canal Development on Mesoamerican Tropical Ecosystems
}

\author{
Alan P. Covich' \\ Odum School of Ecology \\ University of Georgia, Athens, Georgia, United States
}

\section{Introduction}

Having recently celebrated the Centennial of the Ecological Society of America (ESA), it is timely to look back into history as well as to the future regarding how ecologists can effectively inform other scientists, decision-makers, and their own communities about the need for objective ecological information. ESA's focus on Earth Stewardship extends ecological thinking to further define environmental sustainability (Chapin et al., 2015) and facilitates ecologists' continuing contribution to clarifying the fundamental ecological principles underpinning environmental literacy (e.g., Berkowitz et al., 2005; Golley, 1991, 1998). These principles developed over the last 100 years, with the many contributors emphasizing the importance of people being part of natural ecosystems. As the impact of humanity on the functions of our complex adaptive ecosystems is an ongoing and increasing problem today, both the early and current ideas of ecology remain important. Ecologists also continue to create new approaches for resolving these complex problems to avoid unexpected and unwanted consequences (Levin, 1999; Taylor, 2005).

From the perspective that it is important to consider how single individuals have contributed to transforming how both professional ecologists and the public change their thinking about the environment and its dynamic uncertainty, this paper focuses on one individual who served ESA in myriad ways during his long career. This contribution included a major research project on a proposed sea level canal across Darien, Panama (Covich, 2015a, 2015b), which is especially timely to revisit given the recent centennial celebrations for the Panama Canal. Frank Golley inspired numerous students and colleagues to think at multiple scales and to work with other

1 Author contact: alanc@uga.edu 
disciplines to innovate and educate the widest possible audiences. A central theme of Golley's research was the essential importance of connectivity. He emphasized that defining the many connections among people and their understanding of natural systems was critical for resolving environmental problems, from local to global. Golley actively participated in exploring local issues that emphasized how individuals value their historical connections to the land. For example, he enjoyed being a part-time farmer to raise some of his own food for his family. He advocated for protective buffer zones around a local reservoir and many other local and regional issues related to environmental design and planning. At the national and international scales, Golley pioneered the development of landscape ecology and the use of isotopic tracers in detailed food-web studies to demonstrate the importance of biogeochemistry and the bioaccumulation of toxins. His building of new research programs at the University of Georgia's Institute of Ecology and the Savannah River Ecology Laboratory created an academic environment with worldwide intellectual connections (Golley, 2001).

Golley recognized that the challenge was to develop programs that would foster the necessary appreciation of nature by society at large. To be effective, these "nature-centered" programs would also need to include ecological fundamentals for people to achieve both environmental and economic well-being. This challenge to clarify the fundamentals remains, although more students and more among the public are now aware of the critical importance of environmental education and literacy. For example, effective networks among educators, such as the Council of Environmental Literacy, bring together economics, ecologists, and others to exchange information, which in turn provides the public with a science-based perspective on current environmental issues. However, many people still have only a superficial knowledge of what Golley called "connectivity" among environmental issues. Aiding more students, citizens, and policy-makers to obtain objective information on these issues and to develop the critical thinking skills necessary to understand them remains an enormous challenge, especially in developing countries.

Golley's own work to develop international academic programs and his leadership with numerous professional societies and world organizations, from the United Nations Educational, Scientific, and Cultural Organization to the International Society for Ecology, provide an important framework for use today in resolving increasingly complex global problems. Golley recognized the importance of helping the next generation of ecologists learn from firsthand experience about the human dimensions of environmental literacy and environmental ethics. For example, Golley met Stanley Heckadon-Moreno, then a graduate student working on the impacts of deforestation in Darien, at an international meeting in Panama City. Golley encouraged him to seek a career in ecology that would connect the many issues related to tropical deforestation with migrations of poor farmers seeking new lands to convert to pastures. Since those early discussions, many studies by 
Heckadon-Moreno and others in Panama have analyzed the sustainability of the Panama Canal's operation and management of the surrounding rainforest (e.g., Condit et al., 2001; Dale et al., 2005; Heckadon-Moreno, 1993, 2005; HeckadonMoreno et al., 1999). Public outreach and educational programs drawing on the work of these researchers, such as Aqua Salud, have helped to improve policies that retain rainforest cover. The natural vegetation sustains the watersheds and improves the water quality of runoff during intense tropical rainfall (Stallard et al., 2010). Golley also helped to stimulate innovative ideas in environmental ethics among his faculty colleagues, such as the environmental historian Paul Sutter. Sutter (2007, 2009), who has examined a series of human environment issues related to disease control in the early development of the Panama Canal, emphasized the importance of considering multiple viewpoints when reflecting on how people have changed their environment.

Golley's work demonstrated that the basis of environmental stewardship and environmental justice rests on having adequate and objective ecological information to propose alternative solutions to large-scale, complex problems. Most significantly, his research and leadership encouraged many of his colleagues and students to expand their perspectives to include public outreach and to focus on the values of environmental ethics based on sound environmental literacy. Golley (1998) also understood the need for people to connect with each other as global environmental citizens because many issues extend well beyond local, regional, or national boundaries. The growth of environmental education throughout the world has increased awareness and changed how generations relate to the many environmental issues in their communities.

Golley took a landscape approach to understanding the linkages between terrestrial and aquatic components of tropical ecosystems. In the 1960s, many sub-disciplinary specializations in ecology were developing. Golley noted that these sub-groups were too often focusing only on the "trees" and were beginning to literally lose sight of the "forest" as a natural habitat. Golley's view was that natural ecosystems included human interactions along with the many species of plants and animals. His interest in forest structure and function, as well as the succession that followed disturbances, was closely linked to biogeochemical cycles of nutrients and the roles of humans in those cycles. As a biologically trained ecologist, Golley's later development of strong interests in environmental literacy and environmental ethics allowed him to synthesize these areas in a way that continues to engage students, teachers, the public, and professional ecologists.

Golley emphasized that some rare species do have special value and need to have their habitats protected and managed long term. Assemblages of species and their interactions also have high value; management of nature reserves requires a landscape perspective. To achieve and sustain protected areas, Golley emphasized the need for the public to appreciate the value of these areas and to develop an interest in 
their long-term stewardship. In his own ecological research, he highlighted the many ecological and socioeconomic connections affecting ecosystems, especially in tropical regions with exceptionally high biodiversity and significant risk of loss of unique habitats. He expressed concern that policy-makers and planners were not sufficiently aware of these complexities, which needed consideration in large development projects.

\section{What can we learn about the impacts of flooding rainforests?}

The 2015 Centennial of the Panama Canal generated interest in how the first interAmerican canal was completed (e.g., Carse, 2014; Keiner, 2017), and especially in the completion of the current canal expansion project (Rivera \& Sheffi, 2013). The creation of Lake Gatun in 1913 by damming the Chagres River and Lake Alajuela (Madden) in 1934 by damming the Madden River led to the need to manage the region's tropical rainforests and reservoirs to sustain the water supplies for the Panama Canal (Carse, 2014, 2016; Heckadon-Moreno, 1993; Zaret, 1984). Several ongoing, long-term studies analyzing the environmental impacts of these earlier projects provide sources of data. This information could help to estimate some of the costs and benefits of future large-scale construction projects. As any such estimation needs to consider a broad scope of socioeconomic factors, expanded interdisciplinary collaboration is needed well beyond what was available a century ago. Previous research from a long series of studies in Panama provides insights into how tropical ecosystems function. These studies have analyzed, among other things, forest succession and restoration following deforestation and construction, variable water and nutrient budgets, and projections on climate change. Current forest protection programs sustain hydro-ecological functions that provide the freshwater supplies needed for the operation of the Panama Canal and for municipal uses (e.g., Carse, 2012, 2014; Condit et al., 2001; Dale et al., 2005; Ibáńez et al., 2002; Stallard et al., 2010).

\section{A proposed inter-oceanic sea level canal across Darien, Panama}

Golley's studies, along with others from the Darien proposal, illustrate how this perspective could help future generations to transform interdisciplinary studies on the loss of tropical habitats because of mega-projects, such as those that flood rainforests. Golley's study of the rainforest ecosystem of Darien, Panama, was conducted in conjunction with the review of a proposed sea level canal as part of a project to be funded by the United States Atomic Energy Commission (Covich, 2015b). 
Golley's rainforest study contributed to a holistic, landscape-level analysis (Golley et al., 1969, 1975; McGinnis et al., 1969). This proposed additional inter-oceanic canal was intended to complement the existing Panama Canal, which was thought to require a wider channel. More than 50 years since that original proposal, some new wider locks are being added to the original locks from 2016 (Davis et al., 2015). Over time, it became apparent that a new canal through Darien, Panama, was not needed, and that the existing Panama Canal could be expanded safely and with much less environmental impact. Results from the research of Golley and his colleagues contributed to a decade-long series of controversial debates regarding the impacts of the proposed canal as part of Project Plowshare (e.g., Kaufman, 2013; Keiner, 2017; Kirsch, 2005; Rubinoff, 1968). Reflecting on Golley's research on the proposed Darien canal is particularly timely because the collaborative, holistic approach that he developed is still appropriate for mega-projects today.

\section{From Darien, Panama, to the proposed inter-oceanic canal across Nicaragua}

Environmental research-based discussions of decision-making processes are especially relevant now in evaluating the potential impacts of a proposed interoceanic canal to cross Nicaragua. This project would involve dredging a channel across Lake Nicaragua (Lago Cocibolca) and flooding rainforest habitats in the construction of large reservoirs (see Figure 1). The canal dredging would disrupt protected Ramsar wetland sites near the eastern lakeshore. The eastern section of the canal would also intersect the currently protected areas and lands occupied by indigenous and Afro-American groups (e.g., Jordan et al., 2016). If completed, this canal project would be the largest civil excavation ever undertaken. The project, which is being planned by the Hong Kong Nicaragua Development Group, would flood large areas of rainforest and affect water quality (through increased turbidity and salinity) in Lake Nicaragua and its outflow to the Caribbean via Rio San Juan (Environmental Resources Management Group [ERM], 2015). The canal would require construction of a series of large storage reservoirs and hydroelectric production reservoirs to provide a reliable supply of vast amounts of freshwater to sustain use of the locks. However, even the most water- and energy-efficient lock designs are at risk during prolonged dry periods. The water budget and biodiversity of the regions will be significantly affected by how the tropical forests and watersheds are managed to sustain the necessary water supplies to operate the locks (Condit, 2015; ERM, 2015). Reviews by the Nicaragua Academy of Sciences (Acosta, 2015; Huete-Pérez et al., 2015, 2016) and by an independent group of scientists concluded that further detailed studies are needed of the most likely impacts (e.g., Covich et al., 2015). 


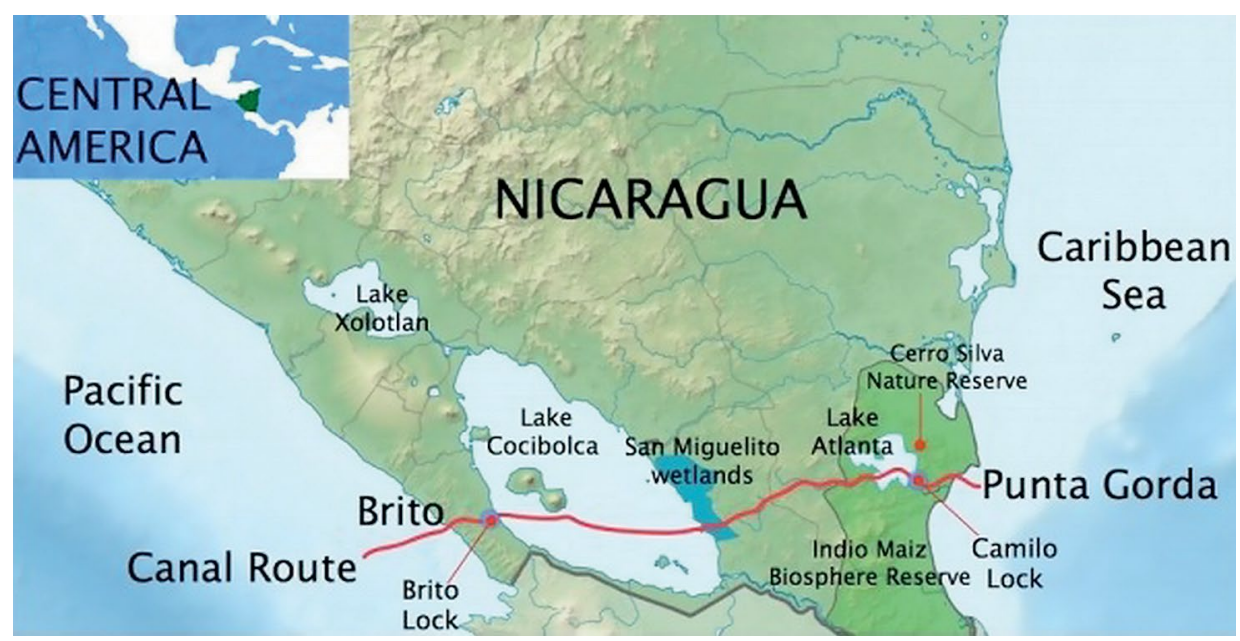

Figure 1: The proposed route of an inter-oceanic canal being planned by the Hong Kong Nicaragua Development Group

Source: S. Espinoza, A. Centeno and C. Solano, in Huete-Pérez et al. (2015), with permission.

Given the increasing uncertainty regarding changing climates and global economics, there is a need for long-term studies of the effects of the project. Excavations for construction of the proposed Brito locks along the western canal route would likely have extensive social and environmental impacts. The canal would link the Brito River and the Las Lajas Rivers for the first time (Muñoz Ardila et al., 2017), resulting in the bi-directional movement of freshwater species between these two river drainage basins and Lake Nicaragua. Mixing of native and non-native invasive species could greatly alter the biodiversity and food web of the lake. Impacts of the proposed excavations on freshwater fish continue to be identified, but much more study is needed (Härer et al., 2017). Large environmental impacts on the Brito River Estuary and unique western tropical dry forest ecosystems are also highly likely (Muñoz Ardila et al., 2017). Moreover, the eastern locks and canal construction would intercept migratory species that rely on the MesoAmerican Biological Corridor and the various river drainages that connect with Lake Nicaragua (e.g., Jordan et al., 2016).

The use of brief snapshots to model ecosystem dynamics has proven inadequate. Many species interactions and socioeconomic responses are non-linear and characterized by tipping points. Consequently, responses to environmental changes can be sudden once thresholds are exceeded or cumulative resulting in the disruption of expected outcomes based on short-term monitoring. This uncertainty can result in major surprises created by complex direct and indirect relationships. For example, a combination of events can change how tropical ecosystems respond to the timing of seasonal and inter-annual variations in extreme rainfall. Natural disturbances such as droughts, hurricanes, volcanic eruptions, and earthquakes can further complicate 
possible cumulative impacts, making it impossible to be prepared for all possible outcomes (e.g., Bommer \& Rodríguez, 2002; Kanamori \& Kikuchi, 1993; Pielke et al., 2003).

The likelihood of some alternative future shipping through a northern sea route creates additional ambiguity regarding the economic values and environmental impacts of the proposed canal construction (e.g., Liu \& Kronbak, 2010; Smith $\&$ Stephenson, 2013). Although considerable uncertainties continue to slow the proposed canal construction, economic geographers have developed several scenarios based on the potential for future shipping through the proposed canal and the savings related to the cost of fossil fuel and carbon accumulation in the atmosphere. Yip and Wong (2015) concluded that "large net benefits are likely to occur from this new canal" (p. 12). However, they did not include any consideration of the social and environmental costs that would likely occur in Nicaragua if the canal were constructed. Nor were the potentially significant costs of marine pollution considered (Chen et al., 2016). Much more interdisciplinary research is needed to evaluate fully how these types of mega-projects can create irreversible environmental and cultural losses before estimating the actual long-term net benefits.

\section{What lessons are learned?}

Golley conducted fundamental research for many decades on how ecosystems function. This experience led to his understanding of the need for regional and global scales of research related to large development projects. Comprehensive study of mega-projects at regional scales using integrated approaches and longterm studies provides the types of insight needed for effective evaluation of these projects and the information necessary to avoid catastrophic local impacts (Covich, 2015a). The results of Golley's research in the 1960s provide an example that can inform current studies of similar mega-projects. It is critically important to avoid the irreversible impacts that these projects can have on natural ecosystems, and especially the people who live in them. The sense of place that multiple generations acquire over their lives is usually undervalued by cost-benefit analyses. The loss of land and the difficulties of relocation can offset benefits and leave local communities impoverished in the long term (Carruthers, 2008; Nygren, 2004). The removal of people from their land to make way for large construction projects in tropical landscapes creates a cascade of disruptions over many years that can include diminished public health and well-being (Wali, 1989).

More than four decades have passed since Golley and others first expressed their concerns about the implementation of large development projects in the tropics without sufficient environmental analysis. Their goal, expressed at that time, remains relevant today: "Our aim is to work within the natural processes and to maintain their 
conservative impacts on the physical degrading process of the planet, with adequate and sustained production" (Golley \& Medina, 1975, p. 3). Further, the many excellent studies over the last five decades mean there is a growing recognition of the value for achieving this goal of holistic approaches that integrate socioeconomic and ecological research into equitable policies. The need for objective science coupled with a concern for transparency and engagement of diverse stakeholders was a main tenet of Golley's ecological perspective. His approach to linking research and policy is needed now as in the past to resolve current environmental issues. Understanding these issues still requires a deep understanding and appreciation for scientific concepts by a wide range of people (Elliott, 2017).

\section{A need for environmental ethics and justice}

Ecologists and other scientists have responded to both the environmental and ethical consequences of economic developments over many decades through their participation in international and interdisciplinary research projects and global efforts to provide environmental justice, especially in Latin America where sustaining biodiversity remains an important concern (Carruthers, 2008; Rozzi, 2015; Wakild, 2013). These interdisciplinary interests focus on how difficult choices can be made that reconcile the needs of conserving habitats while also ensuring people's economic and social well-being (e.g., McShane et al., 2011). Measures that can provide insights regarding the costs and benefits of large construction projects include human wellbeing and societal values of biodiversity. Evaluating the benefits of ecosystem services focuses on the value of sustainability for protecting and managing biodiversity (Brandon, 2014; Dale \& Polasky, 2007; Simonit \& Perrings, 2013). This approach is useful in the analysis of stewardship and managing biodiversity at local and global scales (Golley, 1994; Hall et al., 2011; Mace et al., 2012).

\section{Bioregional, landscape, and local place scale connections}

Golley recognized that comparisons among bioregions must consider the cultural history and current economic concerns that limit options for ecosystem management and sustaining habitat protection in those regions. The combined approach of enhancing the public's basic understanding of ecology through welldeveloped environmental literacy and the professional education of policy-makers and natural resource managers can lead to more sustainable ecosystems. Golley (1991) noted the importance of focusing on beginning students, who can, in turn, inform their families. However, it is difficult to make generalizations that assist in transferring lessons learned in one community or country to another, especially given the enormous differences in biological and cultural diversity that often generate contradictory values. Cultural identity reflects a sense of place, which includes attitudes and values associated with natural resources and biodiversity, among other attributes. Consequently, local, national, and international efforts 
to build a resilient understanding of environmental literacy require a recognition of the different ways that people value their "place" in nature. In some cases, this important link to the land can lead to a strong local consensus on how to sustain ecosystems, but in other cases, the results are increased fragmentation and loss of an integrated approach to bioregional sustainability. This conundrum continues to be a challenge for developing an effective pluralistic environmental literacy. Comparing international perspectives on sustainability and stewardship provides opportunities for learning from successful and unsuccessful outcomes. Too often environmental considerations of mega-projects and economic development in Panama have only had a forestry-centric perspective related to impacts on a few types of diversity. Recent calls to expand the scope of these tropical studies emphasize the need for more comprehensive analyses (e.g., De León \& Lopez, 2016; Velásquez Runk, 2009, 2015, 2017).

\section{A need for long-term studies}

Many developing countries in the tropics, such as Panama and Nicaragua, continue to need evaluation of large-scale development projects, which can result in declining biodiversity and loss of ecosystem services. Planning for sustainable stewardship requires interdisciplinary collaboration to conduct the long-term studies needed for defining the values of different ecosystem services that can be sustained by welldesigned development projects. Environmental history demonstrates that reviewing the full values of development projects often includes multi-generational studies that document conditions before and after project completion. Implementing these studies requires interdisciplinary expertise and comprehensive educational innovations, such as the emphasis on environmental ethics across higher education curricula that Frank Golley championed. Many of the benefits associated with tropical ecosystems are based on cultural use and non-use values, which are often lost when only short-term gains are considered. Knowledge-based planning requires that the current and next generation of ecologists actively engage in communicating what information and values are known in order to avoid irreversible losses.

\section{References}

Acosta, M. L. (2015). El impacto de la ley del Gran Canal Interoceánico de Nicaragua sobre de los pueblos indígenas y Afrodescendientes de Nicaragua. In J. A. HuetePérez, R. L. Gil, \& M. O. Hegg (Eds.), El canal interoceánico por Nicaragua (2nd ed.) (pp. 157-171). Managua: Academia de Ciencias de Nicaragua. 
Berkowitz, A. R., Ford, M. E., \& Brewer, C. A. (2005). A framework for integrating ecological literacy, civics literacy, and environmental citizenship in environmental education. In E. A. Johnson \& M. J. Mappin (Eds.), Environmental education and advocacy: Changing perspectives of ecology and education (pp. 227-266). Cambridge, UK: Cambridge University Press.

Bommer, J. J., \& Rodríguez, C. E. (2002). Earthquake-induced landslides in Central America. Engineering Geology, 63(3-4), 189-220. doi.org/10.1016/ s0013-7952(01)00081-3

Brandon, K. (2014). Ecosystem services from tropical forests: Review of current science (CGD Working Paper 380). Washington, DC: Center for Global Development. Retrieved from www.cgdev.org/publication/ecosystem-services-tropical-forestsreview-current-science-working-paper-380

Carruthers, D. (2008). Environmental justice in Latin America: Problems, promise, and practice. Cambridge, MA: MIT Press.

Carse, A. (2012). Nature as infrastructure: Making and managing the Panama Canal watershed. Social Studies of Science, 42(4), 539-563. doi.org/10.1177/ 0306312712440166

Carse, A. (2014). Beyond the big ditch. Politics, ecology, and infrastructure at the Panama Canal. Cambridge, MA: MIT Press.

Carse, A. (2016). Like a work of nature: Revisiting the Panama Canal's environmental history at Gatun Lake. Environmental History, 21, 231-239.

Chapin III, F. S., Pickett, S. T. A., Power, M. E., Collins, S. L., Baron, J. S., Inouye, D. W., \& Turner, M. G. (2015). Earth stewardship: An initiative by the Ecological Society of America to foster engagement to sustain planet Earth. In R. Rozzi, F. S. Chapin III, J. B. Callicott, S. T. A. Pickett, M. E. Power, J. J. Armesto, \& R. H. May Jr. (Eds.), Earth stewardship: Linking ecology and ethics in theory and practice (pp. 173-194). New York, NY: Springer.

Chen, J., Zeng, X., \& Deng, Y. (2016). Environmental pollution and shipping feasibility of the Nicaragua Canal. Marine Pollution Bulletin, 113(1), 87-93.

Condit, R. (2015). Extracting environmental benefits from a new canal in Nicaragua: Lessons from Panama. PLoS Biology, 13(7): e1002208. doi.org/ 10.1371/journal.pbio. 1002208

Condit, R., Robinson, W. D., Ibáñez, R., Aguilar, S., Sanjur, A., Martínez, R., ... Heckadon, S. (2001). The status of the Panama Canal watershed and its biodiversity at the beginning of the 21st century. Bioscience, 51(1), 389-398. doi.org/10.1641/0006-3568(2001)051[0389:tsotpc]2.0.co;2 
Covich, A. P. (2015a). Frank Golley: International and interdisciplinary insights for a 21st century Earth stewardship. In R. Rozzi, F. S. Chapin III, J. B. Callicott, S. T. A. Pickett, M. E. Power, J. J. Armesto, \& R. H. May Jr. (Eds.), Earth stewardship: Linking ecology and ethics in theory and practice (pp. 431-450). New York, NY: Springer.

Covich, A. P. (2015b). Projects that never happened: Ecological insights from Darien, Panama. Bulletin of the Ecological Society of America, 96(1), 54-63. doi.org/10.1890/0012-9623-96.1.54

Covich, A. P., Crowl, T. A., Stoa, R., Briceno, H., Brett, M., Alvarez, P., Aumem, N., Chandra, S. Heckadon-Moreno, S., Henson, A., Maunder, M., Meyer, A., Olivas, P., Williams-Guillen, K., \& McDowell, W. H. (2015). Summary statement of Nicaragua Canal Environmental Impact Assessment Review Panel. Miami, FL: Florida International University.

Dale, V. H., Brown, S., Calderon, O., Montoya, A. S., \& Martínez, R. E. (2005). Projected land-use change for the eastern Panama Canal watershed and its potential impact. In R. S. Harmon (Ed.), The Rio Chagres, Panama: A multidisciplinary profile of a tropical watershed (pp. 337-345). Dordrecht, Netherlands: Springer.

Dale, V. H., \& Polasky, S. (2007). Measures of the effects of agricultural practices on ecosystem services. Ecological Economics, 64(2), 286-296. doi.org/10.1016/j. ecolecon.2007.05.009

Davis, B., Holmes, R., \& Milligan, B. (2015). Isthmus. Places Journal, December. Retrieved from placesjournal.org/article/isthmus-panama-canal-expansion/

De León, L. F., \& Lopez, O. R. (2016). Biodiversity beyond trees: Panama’s Canal provides limited conservation lessons for Nicaragua. Biodiversity and Conservation, 25(13), 2821-2825. doi.org/10.1007/s10531-016-1197-4

Elliott, K. C. (2017). A tapestry of values: An introduction to values in science. Oxford, UK: Oxford University Press.

Environmental Resources Management Group [ERM]. (2015). Environmental and social impact assessment of the Nicaragua canal. Retrieved from hknd-group.com/ portal.php? $\bmod =$ view\&aid $=293$

Golley, F. B. (1991). Reasoning from ecological knowledge to problem solving. In M. S. Sontag, S. D. Wright, G. L. Young, \& M. Grace (Eds.), Human ecology: Strategies for the future (pp. 52-60). Fort Collins, CO: Society for Human Ecology. 
Golley, F. B. (1994). Rebuilding a humane and ethical decision system for investing in natural capital. In A. M. Janson, M. Hammer, C. Folke, \& R. Constanza (Eds.), Investing in natural capital: The ecological economics approach to sustainability (pp. 169-178). Washington, DC: Island Press.

Golley, F. B. (1998). A primer for environmental literacy. New Haven, CT: Yale University Press.

Golley, F. B. (2001). Establishing the network. In G. W. Barrett \& T. L. Barrett (Eds.), Holistic science: The evolution of the Georgia Institute of Ecology (19402000) (pp. 38-67). New York, NY: Taylor \& Francis.

Golley, F. B., McGinnis, J. T., Clements, R. G., Child, G. I., \& Duever, M. J. (1969). The structure of tropical forests in Panama and Colombia. BioScience, 19(8), 693-696. doi.org/10.2307/1294896

Golley, F. B., McGinnis, J. T., Clements, R. G., Child, G. I., \& Duever, M. J. (1975). Mineral cycling in a tropical moist forest. Athens, GA: University of Georgia Press.

Golley, F. B., \& Medina, E. (Eds.) (1975). Tropical ecological systems: Trends in terrestrial and aquatic research. New York, NY: Springer-Verlag.

Hall, J. S., Ashton, M. S., Garen, E. J., \& Jose, S. (2011). The ecology and ecosystem services of native trees: Implications for reforestation and land restoration in Mesoamerica. Forest Ecology and Management, 261(10), 1553-1557. doi.org/ 10.1016/j.foreco.2010.12.011

Härer, A., Torres-Dowdall, J. T., \& Meyer, A. (2017). The imperilled fish fauna in the Nicaragua Canal zone. Conservation Biology, 31, 86-95.

Heckadon-Moreno, S. (1993). Impact of development on the Panama Canal environment. Journal of Inter-American Studies and World Affairs, 35(3), 129-149. doi.org/10.2307/165971

Heckadon-Moreno, S. (2005). Light and shadows in the management of the Panama Canal Watershed. In R. S. Harmon (Ed.), The Rio Chagres, Panama (pp. 29-44). Amsterdam: Springer.

Heckadon-Moreno, S., Ibanez, R., \& Condit, R. (1999). La Cuenca del Canal: Deforestacion, urbanizacion y contaminacion. Colombia: Imprelibros S.A.

Huete-Pérez, J., Alvarez, P., Schnoor, J., Rittmann, B., Clayton, A., Acosta, M., ... Gonzalez, L. Z. (2015). Scientists raise alarms about fast tracking of transoceanic canal through Nicaragua. Environmental Science and Technology, 49(7), 39893996. doi.org/10.1021/acs.est.5b00215 
Huete-Pérez, J. A., Ortega-Hegg, M., Urquhart, G. R., Covich, A. P., Vammen, K., Rittmann, B. E., Miranda, J. C., Espinoza-Corriols, S., Acevedo, A., Acosta, M. L., \& Gómez, J. P. (2016). Critical uncertainties and gaps in the environmentaland social-impact assessment of the proposed interoceanic canal through Nicaragua. BioScience, 66(8), 632-645.

Ibáñez, R. R. C., Angehr, G., Aguilar, S., Garcia, T., Martínez, R., Sanjur, A., ... Heckadon, S. (2002). An ecosystem report on the Panama Canal: Monitoring the status of the forest communities and the watershed. Environmental Monitoring and Assessment, 80(1), 65-95.

Jordan, C. A., Schank, C. J., Urquhart, G. R., \& Dans, A. J. (2016). Terrestrial mammal occupancy in the context of widespread forest loss and a proposed interoceanic canal in Nicaragua's decreasingly remote South Caribbean Region. PloS one, 11(3), e0151372. doi.org/10.1371/journal.pone.0151372.

Kanamori, H., \& Kikuchi, M. (1993). The 1992 Nicaragua earthquake: A slow tsunami earthquake associated with subducted sediments. Nature, 361, 714716. doi.org/10.1038/361714a0

Kaufman, S. (2013). Project Plowshare. The peaceful use of nuclear explosives in cold war America. Ithaca, NY: Cornell University Press.

Keiner, C. (2017). A two-ocean bouillabaisse: Science, politics, and the Central American sea-level canal controversy. Journal of the History of Biology, 50(4), 835-887. doi.org/10.1007/s10739-016-9461-8

Kirsch, S. L. (2005). Proving grounds: Project Plowshare and the unrealized dream of nuclear earthmoving. New Brunswick, NJ: Rutgers University Press.

Levin, S. (1999). Fragile dominion-Complexity and the commons. Reading, MA: Perseus.

Liu, M., \& Kronbak, J. (2010). The potential economic viability of using the Northern Sea Route (NSR) as an alternative route between Asia and Europe. Journal of Transport Geography, 18, 434-444. doi.org/10.1016/j.trangeo.2009.08.004

Mace, G. M., Norris, K., \& Fitter, A. H. (2012). Biodiversity and ecosystem services: A multilayered relationship. Trends in Ecology and Evolution, 27(1), 19-26. doi.org/10.1016/j.tree.2011.08.006

McGinnis, J. T., Golley, F. B., Clements, R. G., Child, G. I., \& Duever, M. J. (1969). Elemental and hydrologic budgets of the Panamanian tropical moist forest. BioScience, 19(8), 696-697. doi.org/10.2307/1294897 
McShane, T. O., Hirsch, P. D., Chi Trung, T., Songorwa, A. N., Kinzig, A., Monteferri, B., ... O'Connor, S. (2011). Hard choices: Making tradeoffs between biodiversity conservations and human well-being. Biological Conservation, 144(3), 966-972. doi.org/10.1016/j.biocon.2010.04.038

Muñoz Ardila, A., Rebscher, A., \& Hack, J. (2017). Analysis of future land use changes and water availability in the Nicaraguan Southwest as a result of the construction of the Nicaragua Interoceanic Canal. Preprints, 2017090045. doi.org/10.20944/preprints201709.0045.v1

Nygren, A. (2004). Contested lands and incompatible images: The political ecology of struggles over resources in Nicaragua's Indio-Maíz Reserve. Society and Natural Resources, 17(3), 189-205. doi.org/10.1080/08941920490270221

Pielke, R. A., Rubiera, J., Landsea, C., Fernández, M. L., \& Klein, R. (2003). Hurricane vulnerability in Latin America and the Caribbean: Normalized damage and loss potentials. Natural Hazards Review, 4(3), 101-114. doi.org/10.1061/ (asce) 1527-6988(2003)4:3(101)

Rivera, L., \& Sheff, Y. (2013). Panama Canal update. In M. Essig, M. Hülsmann, E.-M. Kern, \& S. Klein-Schmeink (Eds.), Supply chain safety management (pp. 213-216). Berlin: Springer.

Rozzi, R. (2015). Earth stewardship and the biocultural ethic: Latin American perspectives. In R. Rozzi, F. S. Chapin III, J. B. Callicott, S. T. A. Pickett, M. E. Power, J. J. Armesto, \& R. H. May Jr. (Eds.), Earth stewardship: Linking ecology and ethics in theory and practice (pp. 87-112). New York, NY: Springer.

Rubinoff, I. (1968). Central America sea-level canal: Possible biological effects. Science, 161, 861-875. doi.org/10.1126/science.161.3844.857

Simonit, S., \& Perrings, C. (2013). Bundling ecosystem services in the Panama Canal watershed. Proceedings of the National Academy of Sciences, 110(23), 93269331. doi.org/10.1073/pnas.1112242110

Smith, L. C., \& Stephenson, S. R. (2013). New trans-Arctic shipping routes navigable by midcentury. Proceedings of the National Academy of Sciences, 110(13), E1191- E1195.

Stallard, R. F., Ogden, F. L., Elsenbeer, H., \& Hall, J. (2010). Panama Canal watershed experiment: Agua Salud Project. Water Resources Impact, 12(4), 17-20.

Sutter, P. S. (2007). Nature's agents or agents of empire? Entomological workers and environmental change during the construction of the Panama Canal. Isis, 98(4), 724-754. doi.org/10.1086/529265 
Sutter, P. S. (2009). Tropical conquest and the rise of the environmental management state: The case of US sanitary efforts in Panama. In A. McCoy (Ed.), Colonial crucible: Empire in the making of the modern American state (pp. 317-326). Madison, WI: University of Wisconsin Press.

Taylor, P. J. (2005). Unruly complexity-Ecology, interpretation, engagement. Chicago, IL: University of Chicago Press.

Velásquez Runk, J. (2009). Social and river networks for the trees: Wounaan's riverine rhizomic cosmos and arboreal conservation. American Anthropologist, 111, 456-467. doi.org/10.1111/j.1548-1433.2009.01155.x

Velásquez Runk, J. (2015). Creating wild Darién: Centuries of Darién's imaginative geography and its lasting effects. Journal of Latin American Geography, 14(3), 127-156.

Velásquez Runk J. (2017). Crafting Wounaan landscapes: Identity, art, and environmental governance in Panama's Darién. Tucson, AZ: University of Arizona Press.

Wakild, E. (2013). Environmental justice, environmentalism, and environmental history in twentieth-century Latin America. History Compass, 11(2), 163-176. doi.org/10.1111/hic3.12027

Wali, A. (1989). Kilowatts and crisis: Hydroelectric power and social dislocation in eastern Panama. Boulder, CO: Westview Press.

Yip, T. L., \& Wong, M. C. (2015). The Nicaragua Canal: Scenarios of its future roles. Journal of Transportation and Geography, 43, 1-13. doi.org/10.1016/j. jtrangeo.2015.01.002

Zaret, T. (1984). Central American limnology and Gatun Lake, Panama. In F. B. Taub (Ed.), Ecosystems of the world: Lakes and reservoirs (pp. 447-465). New York, NY: Elsevier. 
This text is taken from Human Ecology Review, Volume 23, Number 2, 2017, published 2017 by ANU Press, The Australian National University, Canberra, Australia.

dx.doi.org/10.22459/HER.23.02.2017.05 